\title{
Selectivity of subtidal benthic invertebrate communities for local microalgal production in an estuarine mangrove ecosystem during the post-monsoon period
}

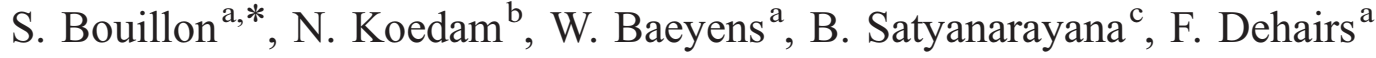 \\ ${ }^{a}$ Department of Analytical and Environmental Chemistry (ANCH), Vrije Universiteit Brussel, Pleinlaan 2, B-1050 Brussels, Belgium \\ ${ }^{\mathrm{b}}$ Department of General Botany and Nature Management (APNA), Vrije Universiteit Brussel, Pleinlaan 2, B-1050 Brussels, Belgium \\ ${ }^{\mathrm{c}}$ Department of Zoology, Marine Biological Laboratory, Andhra University, Visakhapatnam 530003, Andhra Pradesh, India
}

Received 26 November 2002; accepted 21 May 2003

\begin{abstract}
Stable isotope analysis was used as a tool to assess the main carbon sources sustaining the benthic invertebrate communities in an estuarine mangrove ecosystem along the southeast coast of India during the post-monsoon season. In particular, we wanted to test whether the large amounts of terrestrial carbon brought in during the monsoon influence the benthic foodweb in this area, by comparing with earlier data on the pre-monsoon period. The $\delta^{13} \mathrm{C}$ of the dissolved inorganic carbon (DIC) pool was spatially variable, with lower values in the mangrove creeks ( -10.6 to $-8.9 \%$ ) compared to those in the adjacent bay region $\left(-4.3\right.$ to $-2.6 \%$ o). Fixation of the ${ }^{13} \mathrm{C}$-depleted DIC in the mangrove creeks should therefore result in a partial overlap in the $\delta{ }^{13} \mathrm{C}$ signature of mangrove-derived carbon and local phytoplankton. The lack of correlation between $\delta^{13} \mathrm{C}$ values of benthic invertebrates (which showed a large spatial gradient of $\sim 8 \%$ ) and those of sediments or suspended matter (both showing only small spatial gradient of $<2.5 \%$ ) indicates that invertebrates were highly selective for locally produced algal food sources. These results are similar to those obtained during the pre-monsoon period in the same area, although in each region $\delta^{13} \mathrm{C}$ values were consistently more negative (by $1-3 \%$ ) during the post-monsoon period, consistent with the seasonality in $\delta^{13} \mathrm{C}_{\mathrm{DIC}}$. By defining selectivity as the relative spatial gradient in consumer $\delta^{13} \mathrm{C}$ compared to the $\delta^{13} \mathrm{C}$ of bulk particulate organic carbon (POC) and $\delta^{13} \mathrm{C}_{\mathrm{DIC}}$ (as a proxy for the variations expected in local producers), and assuming that the selectivity is similar along the salinity gradient, we estimate that benthic invertebrates rely almost entirely on locally produced microalgal carbon sources. A critical evaluation of earlier studies shows that there is currently no unambiguous evidence for a trophic role of mangrove litter in sustaining subtidal benthic and pelagic invertebrate communities in adjacent aquatic systems.
\end{abstract}

(C) 2003 Elsevier B.V. All rights reserved.

Keywords: Mangrove; Carbon; Nitrogen; Outwelling; Dissolved inorganic carbon; India; Godavari

* Corresponding author.

E-mail address: steven.bouillon@vub.ac.be (S. Bouillon).

\section{Introduction}

The role of mangrove litter in sustaining nearshore or adjacent aquatic secondary production continues to be an issue of debate. Although net export of mangrove carbon may occur in some environmental 
settings (e.g. see Lee, 1995; Dittmar et al., 2001), the limited trophic importance of mangrove-derived carbon has been demonstrated in several ecosystems based on both mass-balance restrictions (e.g. Wafar et al., 1997; Li and Lee, 1998) and evidence from stable isotopes (e.g. Primavera, 1996; Bouillon et al., 2000, 2002a). There are, however, also studies in which mangrove-derived material was reported to be an important food source in the mangrove creeks and -albeit to a limited geographical extent- in the adjacent waters (e.g. Rodelli et al., 1984; Fleming et al., 1990; Chong et al., 2001). A major drawback of many of the latter studies is that their conclusions were based on a comparison of $\delta^{13} \mathrm{C}$ values of invertebrates and those of mangrove litter and a marine phytoplankton end-member (e.g. Chong et al., 2001), without taking into account the possibility that phytoplankton in the creek environment is ${ }^{13} \mathrm{C}$ depleted relative to marine plankton. $\mathrm{A}{ }^{13} \mathrm{C}$-depleted dissolved inorganic carbon (DIC) pool is characteristic of many estuarine and freshwater environments (e.g. Mook and Tan, 1991; Chanton and Lewis, 1999; Hellings et al., 1999), and significant spatial trends in the isotopic composition of the DIC pool are known to occur in mangrove environments as well, as evidenced by both direct $\delta^{13} \mathrm{C}_{\mathrm{DIC}}$ measurements (e.g. Dehairs et al., 2000; Bouillon et al., 2000; S. Marguillier, unpubl. data; Bouillon et al., in press) and by the spatial distribution in seagrass $\delta^{13} \mathrm{C}$ values (Lin et al., 1991; Hemminga et al., 1994; France and Holmquist, 1997; Marguillier et al., 1997). As this DIC becomes incorporated by phytoplankton and other local aquatic primary producers, the use of a typical 'marine' $\delta{ }^{13} \mathrm{C}$ reference value for phytoplankton becomes inappropriate and will result in a significant overestimation of the importance of mangrove detritus. In such cases, knowledge or estimation of phytoplankton $\delta^{13} \mathrm{C}$ values may be crucial, although evidence of selectivity for algal sources may also be derived from seasonal or spatial $\delta^{13} \mathrm{C}$ variations. Thus, even though the hypothesis that mangrove litter sustains or contributes to aquatic secondary production is often quoted as one of the arguments for the preservation of these ecosystems and as one of its major ecosystem functions, results from some studies may need to be interpreted cautiously. On the other hand, results obtained in one site cannot simply be generalised due to the large environmental variability found in mangrove ecosystems and their carbon dynamics (e.g. see Dittmar and Lara, 2001).

Mangrove ecosystems have long been recognised as important nursery habitats for fish, although the relative importance of estuarine conditions and the presence of mangroves remains unclear (Vidy, 2000). A large number of fish species in mangrove ecosystems are benthic invertebrate feeders (see Robertson and Blaber, 1992), with access to invertebrate communities in both adjacent waters (which may harbour seagrass beds and coral reefs), mangrove creeks, and intertidal zones. In this context, the extent to which benthic invertebrate communities in these different areas use mangrove litter (directly or indirectly) as a food source will determine the importance of mangrove primary production in sustaining fish communities. In previous studies in the same site, we found a clear selectivity for local algal food sources in zooplankton and subtidal benthic invertebrates during the pre-monsoon period (Bouillon et al., 2000, 2002a). Similarly, benthic fauna in the intertidal areas made surprisingly little use of mangrove litter (Bouillon et al., 2002b) but, in contrast to subtidal benthic invertebrates, showed a highly diverse pattern of resource utilisation.

In this study, we wanted to verify whether our earlier findings on the carbon sources sustaining invertebrate communities in the Godavari delta mangrove ecosystem during the pre-monsoon period (Bouillon et al., 2002a) would remain valid during the post-monsoon season. As large amounts of terrestrial organic carbon are transported by the Godavari river during the monsoon (Gupta et al., 1997), it could be hypothesised that the influence of terrestrial carbon in the benthic foodwebs might be more pronounced than during the pre-monsoon. We propose a simplified definition for the selectivity of the invertebrate community for locally produced algal carbon versus terrestrial/mangrove-derived carbon. In addition, we wanted to verify whether the strong spatial trend in consumer $\delta^{13} \mathrm{C}$ (which holds potential in using $\delta^{13} \mathrm{C}$ as a natural tracer for migration or local feeding patterns of mobile species, e.g. see Fry et al., 1999) is maintained during this season. Finally, based on these new results we provide a critical overview of previous studies on the trophic fate of exported mangrove litter, and propose that little or no unambiguous evidence for a significant trophic role has been found. 


\section{Materials and methods}

\subsection{Study area}

The sampling sites (Fig. 1) are located in the area between Kakinada Bay and the Gautami branch of the Godavari, situated in the south-eastern state of Andhra Pradesh (between $82^{\circ} 15^{\prime}$ and $82^{\circ} 22^{\prime} \mathrm{E}$, $16^{\circ} 43^{\prime}$ and $17^{\circ} 00^{\prime} \mathrm{N}$ ). The Godavari is considered one of the largest POC (particulate organic carbon) transporting rivers in the world (Gupta et al., 1997). The Gautami branch opens into the Bay of Bengal, but has several connections into Kakinada Bay, including Coringa and Gaderu (Fig. 1). The area between river and bay is covered by extensive mangrove forests and tidal mudflats and a multitude

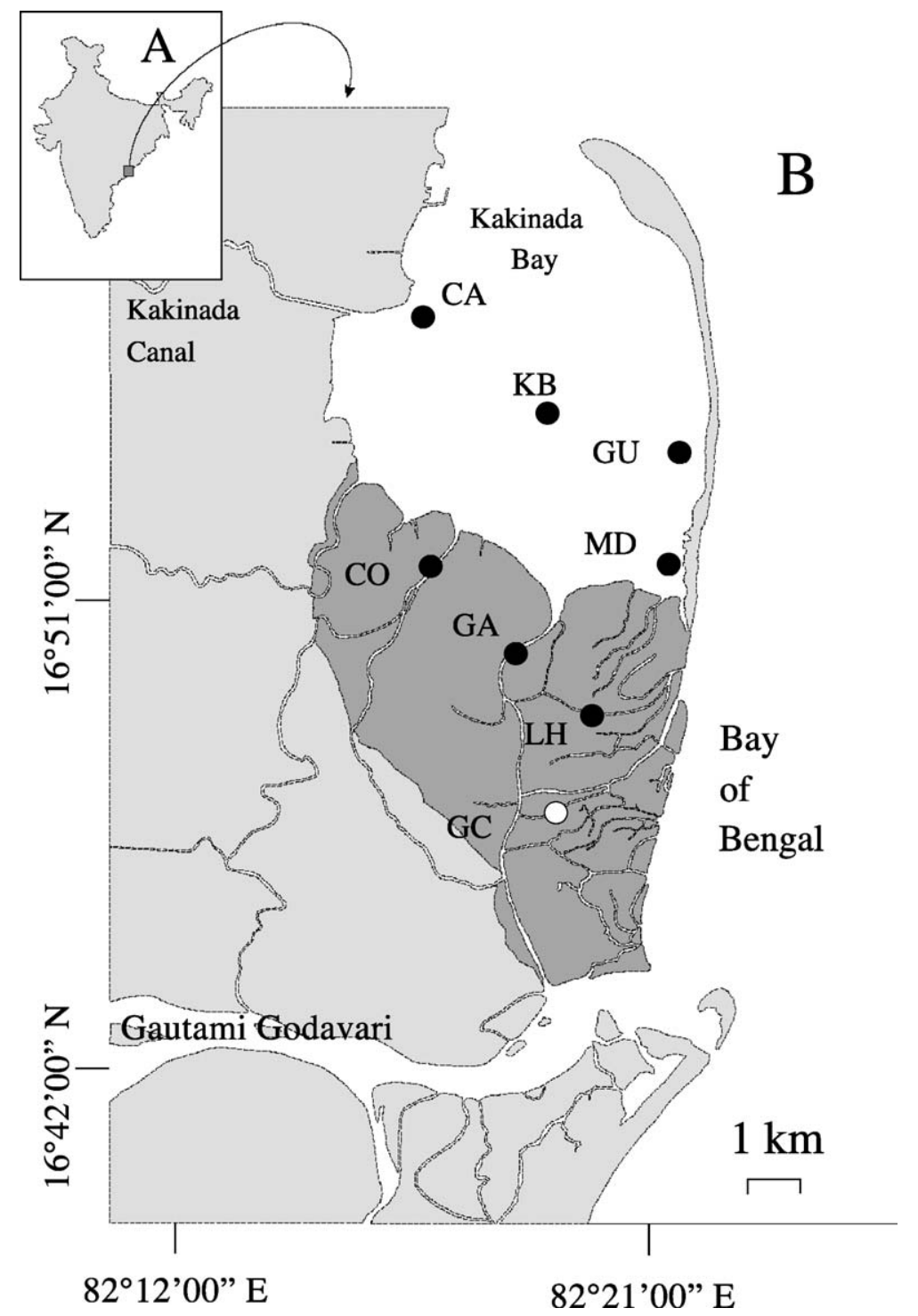

Fig. 1. Map of the study area and sampling sites (black circles) with their abbreviations. The white circle represents a sampling site for DIC and POC size fractions only. The darkest part represents the main mangrove-covered area. 
of interconnected tidal creeks. Kakinada Bay (depth ranging from 3 to $8 \mathrm{~m}$ at high tide) covers approximately $150 \mathrm{~km}^{2}$ and opens into the Bay of Bengal on its northern side, bordered along most of its eastern length by a narrow sand bar (Hope Island). Monsoon rainfall in the area usually occurs between July and September, during which near-freshwater conditions are found in the southern part of the study area. During the sampling period of this study, estuarine to marine conditions had re-established with salinity ranging between 20 and 28 ppt, and total suspended matter concentrations were between 44 and $111 \mathrm{mg}^{-1}$.

\subsection{Sample collection and preparation}

DIC samples for $\delta^{13} \mathrm{C}$ analysis were collected by gently overfilling a glass bottle with surface water, poisoning with $100 \mu \mathrm{l}$ of a saturated $\mathrm{HgCl}_{2}$ solution, and gas tight capping with a rubber plug and aluminium cap. Salinity was measured in the field using a refractometer. Total suspended matter was sampled by filtering $250 \mathrm{ml}$ of surface water on pre-combusted glassfibre filters (Whatman GF/ F), the $<10 \mu \mathrm{m}$ fraction was obtained by passing $250 \mathrm{ml}$ of surface water through a $10 \mu \mathrm{m}$ nylon screen, after which the water was filtered on precombusted $\mathrm{GF} / \mathrm{F}$ filters. Two intermediate size fractions $(10 \ll 50 \mu \mathrm{m}$ and $50 \ll 118 \mu \mathrm{m})$ were obtained by towing custom-designed plankton nets for several minutes, the fractions were collected on screens of the lower mesh size and dried as such. Benthic fauna and sediments were collected using a dredge and Van Veen grab, and were kept in a cool box on board. The species sampled were the bivalves Anadara granosa, Meretrix meretrxi, Placuna placenta, Solen pecten, and Tellina sp., the gastropods Murex trapa and Nassarius sp. (both occupying a higher trophic level; all others mentioned are considered lower trophic level species), and the brachyuran crabs Dorippe facchino and Typhlocarcinus sp. After transportation to the field laboratory, all faunal samples were washed and dried at $60{ }^{\circ} \mathrm{C}$ for at least $24 \mathrm{~h}$. All organic samples (excluding filters) were later ground to a fine powder. Sub-samples for $\delta^{13} \mathrm{C}$ analysis were treated with dilute $\mathrm{HCl}$ in silver cups to remove possible carbonates, and re-dried.

\subsection{Measurement of stable isotope and elemental ratios}

Carbon isotope analysis of DIC was performed as described by Hellings et al. (1999). All organic samples for stable isotope analysis were combusted in a Carlo Erba NA-1500 Elemental Analyser and the resulting gases $\left(\mathrm{CO}_{2}\right.$ and $\left.\mathrm{N}_{2}\right)$ were cryogenically separated using a manual extraction line. Stable isotope ratios were then determined on a Finnigan Mat Delta E isotope ratio mass spectrometer and are expressed relative to the conventional standards, i.e. PDB limestone for carbon and atmospheric $\mathrm{N}_{2}$ for nitrogen, as $\delta$ values, defined as:

$\delta \mathrm{R}=\left[\frac{\mathrm{X}_{\text {sample }}-\mathrm{X}_{\text {standard }}}{\mathrm{X}_{\text {standard }}}\right] * 10^{3}[\% o]$

where $\mathrm{R}={ }^{13} \mathrm{C}$ or ${ }^{15} \mathrm{~N}$, and $\mathrm{X}={ }^{13} \mathrm{C} /{ }^{12} \mathrm{C}$ or ${ }^{15} \mathrm{~N} /{ }^{14} \mathrm{~N}$. Standard deviations on ten aliquots of the same sample were lower than $0.2 \%$ for both $\delta^{13} \mathrm{C}$ and $\delta{ }^{15} \mathrm{~N}$. Elemental (POC/PN, atom) analysis of suspended organic matter was performed by combusting acid-fumed filters or HCl-treated material in a Carlo Erba NA-1500 Elemental Analyser.

\section{Results}

\subsection{Dissolved inorganic carbon (DIC)}

$\delta^{13} \mathrm{C}$ values of the DIC pool varied between -10.6 and $-2.6 \%$, with significantly lower values $(-10.6$ to $-8.9 \%$ ) in the mangrove creeks compared to those in the bay region $(-4.3$ to $-2.6 \%$ ). There was, however, no relationship between $\delta^{13} \mathrm{C}_{\mathrm{DIC}}$ and salinity (figure not shown).

\subsection{Suspended and sedimentary organic carbon}

$\delta^{13} \mathrm{C}$ values for different size fractions of POC ranged overall between -29.2 and $-19.5 \%$, and significant differences were found between different size fractions (Table 1, Fig. 2B), but not between locations (single-factor ANOVA). Whereas the total POC and the $<10 \mu \mathrm{m}$ fraction were relatively depleted in ${ }^{13} \mathrm{C}$ in all sampling locations with similar and fairly uniform $\delta^{13} \mathrm{C}$ values between of $-27.5 \pm$ 
Table 1

Carbon isotopic composition $\left(\delta^{13} \mathrm{C}\right.$, in $\%$ o of different size-fractions of suspended matter, sediments, and dissolved inorganic carbon (DIC) from 8 locations within the Coringa-Kakinada Bay system in December 1999

\begin{tabular}{|c|c|c|c|c|c|c|c|c|}
\hline & \multicolumn{4}{|c|}{ Mangrove creeks } & \multicolumn{4}{|c|}{ Bay locations } \\
\hline & M1 & M2 & M3 & M4 & B1 & B2 & B3 & B4 \\
\hline \multicolumn{9}{|c|}{ Suspended organic matter size fractions } \\
\hline$<10 \mu \mathrm{m}$ & -26.5 & -25.6 & -29.2 & n.d. & -27.6 & -28.5 & -26.8 & -27.1 \\
\hline $10 \ll 50 \mu \mathrm{m}$ & -24.9 & -25.7 & -26.2 & -26.9 & -22.9 & -22.3 & -24.6 & -24.9 \\
\hline $50 \ll 118 \mu \mathrm{m}$ & -25.9 & -24.7 & -25.5 & -25.6 & -22.6 & -20.6 & -19.5 & -21.4 \\
\hline Total & -28.1 & -25.6 & -26.4 & -28.5 & -26.7 & -28.9 & -28.3 & -27.7 \\
\hline \multicolumn{9}{|l|}{ Sediments } \\
\hline Bulk & -21.4 & -23.1 & -22.5 & n.d. & -23.3 & -21.4 & -20.8 & -21.5 \\
\hline Dissolved organic carbon & -9.8 & -10.0 & -10.6 & -8.9 & -3.7 & -2.6 & -4.3 & -3.1 \\
\hline
\end{tabular}

n.d.: not determined.

$1.2 \%$ and $-27.3 \pm 1.2 \%$, respectively, the intermediate fractions $(10 \ll 50 \mu \mathrm{m}$ and $50 \ll 118 \mu \mathrm{m})$ were spatially more variable with generally more depleted values in the mangrove creeks (Fig. 2B). In general, $\delta^{13} \mathrm{C}$ values increased markedly from the $<10$ $\mu \mathrm{m}$ fraction over the $10 \ll 50 \mu \mathrm{m}$ fraction to the $50 \ll 118 \mu \mathrm{m}$ fraction for samples from the bay region, but this trend was much less pronounced in the creek locations (Fig. 2B). POC/PN ratios were generally low (range: 4.5 to 9.4), being most variable in the $50 \ll 118 \mu \mathrm{m}$ fraction (Fig. 2A). POC/PN ratios of the total suspended matter pool $(6.6 \pm 0.6)$ were significantly lower than those of the $<10 \mu \mathrm{m}$ fraction $(7.9$ $\pm 0.8)$ and the $10 \ll 50 \mu \mathrm{m}$ fraction $(8.1 \pm 0.5)$, but no significant between-site differences were detected. Whereas $\delta^{13} \mathrm{C}$ values indicated similarities between the $<10 \mu \mathrm{m}$ and total POC fractions and between the $10 \ll 50$ and $50 \ll 118 \mu \mathrm{m}$ fractions, $\mathrm{POC} / \mathrm{PN}$ ratios were similar in the $<10 \mu \mathrm{m}$ and $10 \ll 50 \mu \mathrm{m}$ fractions and in the $50 \ll 118 \mu \mathrm{m}$ and total POC fractions (single factor ANOVA). Note that our data (in particular those from the mangrove creeks) suggest that an additional fraction should be taken into account in order to explain the POC/PN ratios of the total suspended matter pool as a combination of the three fractions mentioned (see Fig. 2A), i.e. our data sug-
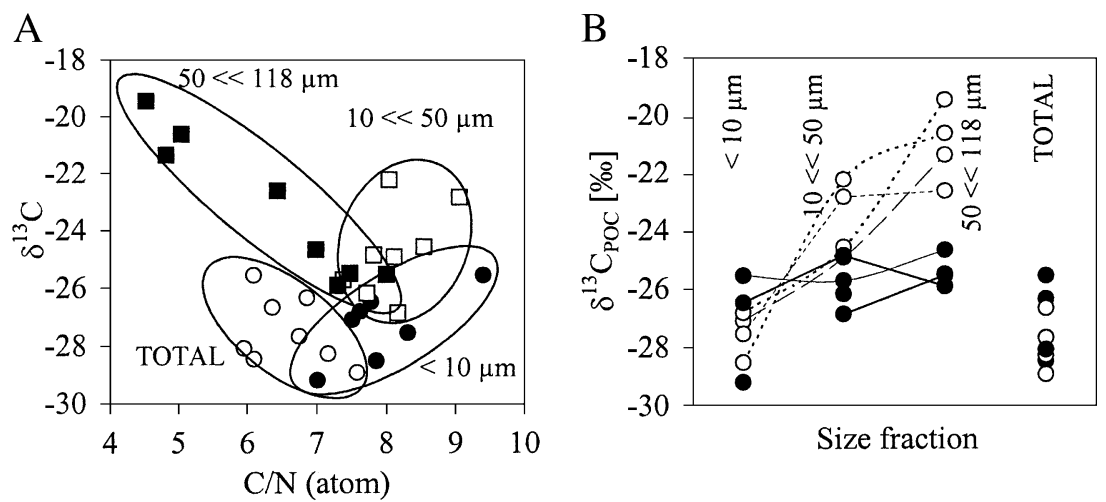

Fig. 2. (A) Elemental composition (POC/PN, atom) versus $\delta^{13} \mathrm{C}$ of total and size-frationated POC (open circles: total; open squares: $10 \ll 50 \mu \mathrm{m}$; black circles: $<10 \mu \mathrm{m}$; black squares: $50 \ll 118 \mu \mathrm{m}$ ), and (B) variations in $\delta^{13} \mathrm{C}$ across POC size classes. Open symbols represent bay locations (B1-B4), black symbols represent mangrove creek locations (M1-M4). Note that the ovals in panel A merely serve to group data from similar size fractions visually. 
gest the existence of a relatively ${ }^{13} \mathrm{C}$-depleted fraction with a low $\mathrm{POC} / \mathrm{PN}$ ratio.

Sediments displayed a fairly narrow range of $\delta^{13} \mathrm{C}$ values, with only slightly lower values in the mangrove creeks $(-23.1$ to $-21.4 \%$ ) compared to the bay locations $(-23.0$ to -20.8$)$. On the basis of this limited number of samples, there appears to be hardly any spatial gradient in sediment $\delta^{13} \mathrm{C}$ between creeks and bay (Table 1).

\subsection{Benthic invertebrates}

$\delta^{13} \mathrm{C}$ values of invertebrates during this survey (Table 2, Fig. 3) showed a marked spatial trend, with generally depleted average values in the three mangrove creeks (M1: $-27.6 \%$, M2: $-27.3 \%$, and M3: $-25.6 \%$ ), intermediate values in the south-east bay locations (B1: $-20.7 \%$, B2: $-20.5 \%$ ) and most enriched values in the central bay locations (B3: $-18.2 \%$ o for lower trophic levels, $-16.3 \%$ o for high trophic level species, B4: $-18.8 \%$ o). Invertebrates from the three mangrove creek locations (which were all classified as lower trophic levels, see Bouillon et al., 2002a) had comparable $\delta^{15} \mathrm{~N}$ values (averages M1: $+5.9 \%$, M2: $+6.2 \%$, and M3: $+6.2 \%$ ), which were about $3 \%$ lower than those found in low trophic level invertebrates from the bay locations (average B1: $+9.0 \%$ o, B2: +9.2\%o, B3: $+8.8 \%$, B4: $+8.9 \%$, Fig. 3). The two higher trophic level

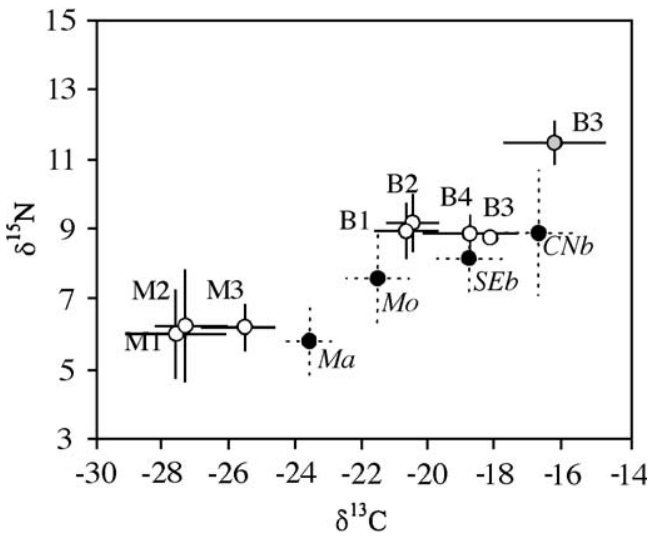

Fig. 3. Plot of $\delta^{13} \mathrm{C}$ and $\delta^{15} \mathrm{~N}$ data for benthic invertebrates collected during post-monsoon period (open symbols: lower trophic levels; grey symbol: higher trophic level species), and a comparison with pre-monsoon data (black symbols; taken from Bouillon et al. (2002a), data for lower trophic level species only). Ma: mangrove creek locations; Mo: mangrove outlets; SEb: south-eastern bay; $\mathrm{CNb}$ : central and northern bay, see also Bouillon et al. (2002a) for details. Other abbreviations as in Fig. 1. Error bars $=1$ s.d.

species from station B3 (the gastropods Murex trapa and Nassarius sp.) showed a distinct enrichment in both $\delta^{13} \mathrm{C}$ and $\delta^{15} \mathrm{~N}$ (Fig. 3). Although invertebrates in Gaderu creek were found to be on average slightly enriched compared to those in other mangrove creeks, this may be due to the small amount of individuals analysed: Tellina sp. from the three mangrove creeks were isotopically similar (Fig. 4), the only additional

Table 2

Average carbon and nitrogen stable isotopic composition (in \%o, \pm 1 s.d) of benthic invertebrates (low trophic levels, unless otherwise specified) at different sampling locations in December 1999

\begin{tabular}{lllcc}
\hline & average $\delta^{13} \mathrm{C}$ & range $\delta^{13} \mathrm{C}$ & average $\delta^{15} \mathrm{~N}$ & range $\delta^{15} \mathrm{~N}$ \\
\hline Mangrove creeks & & & & \\
M1 & $-27.6 \pm 1.5$ & -30.2 to -25.9 & $+5.9 \pm 1.2$ & +4.4 to +7.7 \\
M2 & $-27.3 \pm 0.9$ & -28.8 to -26.1 & $+6.2 \pm 1.6$ & +4.5 to +8.6 \\
M3 & $-25.6 \pm 0.9$ & -26.1 to -24.2 & $+6.2 \pm 0.6$ & +5.4 to +6.9 \\
Bay locations & & & & \\
B1 & $-20.7 \pm 1.0$ & -21.8 to -19.6 & $+9.0 \pm 0.8$ & +8.3 to +9.7 \\
B2 & $-20.5 \pm 0.8$ & -21.8 to -19.5 & $+9.2 \pm 0.8$ & +8.5 to +10.7 \\
B3 & -18.2 & -18.3 to -18.1 & +8.8 & +8.8 to +8.8 \\
B3 $^{\text {b }}$ & $-16.3 \pm 1.5$ & -17.8 to -14.7 & $+11.6 \pm 0.6$ & +10.8 to +12.2 \\
B4 & $-18.8 \pm 1.4$ & -20.5 to -17.0 & $+8.9 \pm 0.5$ & +8.2 to +9.6 \\
\hline
\end{tabular}

See text for details.

$\mathrm{N}$ : number of samples.

${ }^{\text {a }}$ Low trophic level species.

${ }^{\mathrm{b}}$ High trophic level species. 


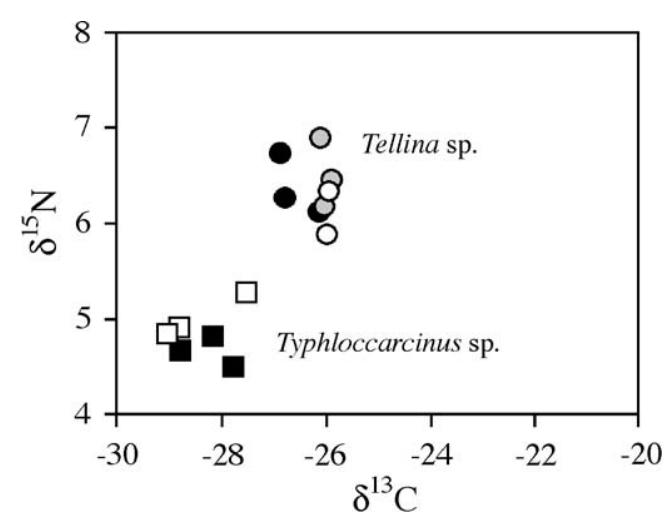

Fig. 4. Carbon and nitrogen stable isotope composition of individual Tellina sp. (circles) and Typhlocarcinus sp. (squares) from the three mangrove creek locations. Black symbols: data from station M2; grey symbols: station M3; open symbols: station M1.

species from Gaderu was relatively enriched (Macroophthalmus sp.) whereas other species collected in M1 and M2 were more depleted (e.g. Solen pecten, Typhlocarcinus sp.).

\section{Discussion}

\subsection{Dissolved inorganic carbon}

The low $\delta^{13} \mathrm{C}_{\text {DIC }}$ values reported here in the mangrove creeks are consistent with earlier preliminary data from Coringa creek and with recent more intensive surveys of $\delta^{13} \mathrm{C}_{\text {DIC }}$ in the area (Bouillon et al., in press). In the bay area, however, the values observed are typical for the monsoon and early postmonsoon season, and during the rest of the year, the DIC pool in the area has more typically marine values (results not shown). These direct measurements therefore confirm that local primary producers in the water column (i.e. phytoplankton, microphytobenthos) should exhibit a spatial gradient in their $\delta^{13} \mathrm{C}$ signature, with more negative values in the mangrove creeks and less depleted values in the bay region, as suggested previously based on $\delta^{13} \mathrm{C}$ measurements of bulk suspended matter and zooplankton (Dehairs et al., 2000; Bouillon et al., 2000). Although it is well established that the degree of fractionation between DIC and phytoplankton is variable to some extent, depending on factors such as $\left[\mathrm{CO}_{2 \mathrm{aq}}\right]$, temperature and growth rate (e.g. Rau et al., 1992; Hinga et al., 1994), a constant value between 18 to $22 \%$ is often used as a first-order estimate of the $\delta^{13} \mathrm{C}$ signature of phytoplankton (e.g. Cai et al., 1988; Ogawa and Ogura, 1997; Hellings et al., 1999). The thus estimated $\delta^{13} \mathrm{C}$ values for phytoplankton partially overlap with those for mangrove litter, making it unreliable to estimate the relative contribution of these two possible carbon sources to invertebrates using simple two-end mixing calculations. It should be noted that the relatively large variations in $\delta^{13} \mathrm{C}_{\mathrm{DIC}}$ ( $\sim 7 \%$ o during this study) occurred over a remarkably short distance $(\sim 5 \mathrm{~km})$, yet variations of a similar magnitude have been suggested previously in mangrove environments based on $\delta^{13} \mathrm{C}$ data of seagrasses and mollusc carbonates (Lin et al., 1991; Hemminga et al., 1994; France and Holmquist, 1997; Marguillier et al., 1997).

\subsection{Suspended matter and sediments}

The significant differences found in $\delta^{13} \mathrm{C}$ on the one hand and $\mathrm{POC} / \mathrm{PN}$ ratios on the other hand between various size classes of suspended matter (Table 1, Fig. 2) indicate that the composition of these particles and their origin were markedly different. The fact that different patterns of similarity were found based on $\delta^{13} \mathrm{C}$ and $\mathrm{POC} / \mathrm{PN}$ ratios suggests that, although the $<10 \mu \mathrm{m}$ fraction appeared to be the dominant particulate organic matter pool in terms of carbon, other fractions (e.g. $50 \ll 118 \mu \mathrm{m}$ ) contributed more in terms of $\mathrm{N}$. Weight measurements confirm that the $<10 \mu \mathrm{m}$ fraction comprised on average $90 \pm 27 \%$ (DW) of the total suspended matter pool during this sampling period, but as the contribution was estimated to be $>100 \%$ in 3 out of 7 cases these should be interpreted with caution. Similarly, the contribution of the $<10 \mu \mathrm{m}$ fraction to the total POC pool (using the $\delta^{13} \mathrm{C}$ values and $\mathrm{POC} /$ $\mathrm{PN}$ ratios in a 3-source mixing model) appears to be dominant, although it should be stressed that for several stations, mixing of the 3 size fractions is insufficient to explain the observed $\mathrm{POC} / \mathrm{PN}$ ratios and $\delta^{13} \mathrm{C}$ values in the total suspended matter. Whereas the $\delta^{13} \mathrm{C}$ signature of the $<10 \mu \mathrm{m}$ fraction and the total POC did not vary with the $\delta^{13} \mathrm{C}_{\text {DIC }}$, the intermediate fractions showed more pronounced spa- 
tial variability parallel with DIC stable isotope composition (Table 1). The latter suggests that photoautotrophs (i.e. phytoplankton) were a major component of the intermediate size classes. Initial results of microscopical examinations of different size fractions of suspended matter (April and May 2001, C. Kalavati and A.V. Raman, Andhra University, pers. comm.) indicate major differences in the biological composition of these fractions, with a dominance of phytoplankton (diatoms, flagellates) in the $10 \ll 50 \mu \mathrm{m}$ and $50 \ll 118 \mu \mathrm{m}$ classes. Most enriched $\delta^{13} \mathrm{C}$ values (in the $50 \ll 118 \mu \mathrm{m}$ fraction in stations $\mathrm{B} 2-\mathrm{B} 4)$ coincided with very low $\mathrm{POC} / \mathrm{PN}$ ratios (4.5 to 5.1), and although such low $\mathrm{POC} / \mathrm{PN}$ ratios have previously been found in e.g. sewagederived organic matter (e.g. Faganeli et al., 1988: 4.7 \pm 0.9 ), it is unlikely that this could offer an explanation in our study, as the $\delta^{13} \mathrm{C}$ values are not indicative of a terrestrial source. A contribution by microzooplankton or a major bacterial colonisation could possibly explain the low POC/PN ratios observed in these samples (see also Results). Similar trends of increasing $\delta^{13} \mathrm{C}$ values with size have been found in other studies (e.g. Rau et al., 1990; Middelburg and Nieuwenhuize, 1998; Leggett et al., 1999). Finally, the narrow range of $\delta^{13} \mathrm{C}$ values in sediments (Table 1) is in agreement with previous findings in the area (Bouillon et al., 2002a) and the discrepancy between the observed $\delta^{13} \mathrm{C}$ values and those for terrestrial (including mangrove) vegetation confirms the limited terrestrial contribution to the total sediment organic carbon pool in the mangrove creeks and bay area.

\subsection{Invertebrate $\delta^{13} C$ and $\delta^{15} N$}

In a previous study in this area we found that subtidal benthic invertebrates showed a spatial trend of $\delta^{13} \mathrm{C}$ and $\delta^{15} \mathrm{~N}$ values during the pre-monsoon period, with lowest values found in the mangrove creeks and elevated values in the central bay (Bouillon et al., 2002a). Although the general trend in $\delta^{13} \mathrm{C}$ found during the pre-monsoon period was confirmed in the actual post-monsoon data, there were 2 major differences: (1) there is a tendency for $\delta^{13} \mathrm{C}$ values to be more depleted than during the pre-monsoon season by $1-3 \%$ o throughout the area, and (2) the overall spatial gradient in $\delta^{13} \mathrm{C}(\sim 8.5 \%)$ was even more pronounced than during the pre-monsoon season $\left(\sim 7 \%\right.$ ) . No seasonal change in invertebrate $\delta^{15} \mathrm{~N}$ was evident. Although the focus in this study was to collect lower trophic level species (see Materials and methods section), the isotope data for Murex trapa and Nassarius sp. from station B3 confirm the higher $\delta{ }^{15} \mathrm{~N}$ values found previously in these scavengers/ predators (Bouillon et al., 2002a). The $\delta^{15} \mathrm{~N}$ data show two very distinct distributions, with invertebrates from mangrove creeks and those from the bay regions being separated by $\sim 3 \%$ with hardly any overlap (Fig. 3). This clear segregation suggests a limited exchange of material between these two regions, which was also evident from the $\delta^{13} \mathrm{C}$ distribution of DIC (Table 1). Alternatively, it could indicate that substantial transformation processes (e.g. uptake, denitrification) take place before N-pools from the mangrove creeks reach the bay.

The $\delta{ }^{13} \mathrm{C}$ values of benthic invertebrates from the creeks show a partial overlap with those of mangrove litter, but there are a number of arguments which strongly suggest that these depleted values are not related to direct utilization of mangrove litter by invertebrates. The wide range of $\delta{ }^{13} \mathrm{C}$ values $(>10 \%)$ in individual invertebrates is in sharp contrast with the limited spatial variability in bulk sediment and suspended matter $\delta^{13} \mathrm{C}$ values. This indicates the selectivity of the invertebrate community for components that are spatially more variable in $\delta^{13} \mathrm{C}$ than the bulk of the available organic matter. Invertebrate $\delta^{13} \mathrm{C}$ values follow the trend observed in $\delta^{13} \mathrm{C}_{\mathrm{DIC}}$ values, and as low $\delta^{13} \mathrm{C}_{\mathrm{DIC}}$ values are expected to result in phytoplankton $\delta^{13} \mathrm{C}$ values which are significantly depleted relative to typical marine plankton (between - 32.9 and $-27.9 \%$ ), there would be a good agreement between expected $\delta^{13} \mathrm{C}$ values for local plankton and invertebrates.

The limited importance of mangrove litter, both in the mangrove creeks and in the adjacent waters, is in agreement with results from several other studies (e.g. Primavera, 1996; Bouillon et al., 2000; Lee, 2000) but it stands in contrast to the conclusions from other studies employing stable isotope analysis that mangrove carbon significantly contributes to foodwebs in the mangrove creeks, with a decreasing importance towards the open marine environment (e.g. Rodelli et al., 1984; Fleming et al., 1990; Chong 
et al., 2001). Here, it is important to stress that none of the latter studies considered the existence of a ${ }^{13} \mathrm{C}$ depleted DIC pool in the mangrove creeks and used typical marine phytoplankton $\delta^{13} \mathrm{C}$ signatures to evaluate the relative importance of aquatic production and mangrove litter, thus potentially overestimating the contribution of the latter. In fact, Chong et al. (2001), citing Hayase et al. (1999), provided some indirect evidence for the existence of ${ }^{13} \mathrm{C}$-depleted phytoplankton in the mangrove creeks of their study by noting that $\delta^{13} \mathrm{C}$ values of total suspended organic matter showed a large spatial gradient between the mangrove creeks and the marine environment $(-25.6$ to $-17.9 \%$ o $)$ whereas the estimated contribution of phytoplankton (based on Chl-a measurements) changed very little over the same gradient (from 17 to $25 \%$ ). Such a discrepancy strongly suggests that phytoplankton in the creeks was depleted in ${ }^{13} \mathrm{C}$ by at least $5 \%$ (although it should be noted that a terrestrial contribution of $\sim 80 \%$ is difficult to explain with a $\delta^{13} \mathrm{C}$ of $-17.9 \%$ ). Schwamborn et al. (2002), despite finding clear evidence for selective feeding of various zooplanktonic crustaceans on phytoplankton, estimated the contribution of mangrove detritus to the carbon requirements of copepods to be $13-40 \%$ in a Brazilian mangrove estuary, but based these estimates on a two-end mixing equation, with mangroves and phytoplankton-the latter being given a value of $-21.3 \%$, typical of marine phytoplankton.

In other mangrove ecosystems, both direct measurements (e.g. Bouillon et al., in press; S. Marguillier, unpubl. data: $\delta^{13} \mathrm{C}_{\mathrm{DIC}}$ between -8.9 and $+0.2 \%$ in Gazi Bay, Kenya) and indirect evidence based on the $\delta^{13} \mathrm{C}$ of seagrasses or macroalgae (e.g. Hemminga et al., 1994) also indicate that the inorganic carbon pool (and as a result also local phytoplankton) is depleted in ${ }^{13} \mathrm{C}$ compared to the marine end-member. Although the still often-quoted hypothesis that exported mangrove litter supports local (and possibly adjacent) aquatic foodwebs will no doubt continue to be an issue of debate, we feel that there is currently little or no unambiguous evidence to support this view. The generation of more studies using stable isotopes, mass balance equations, and/or other tracer techniques such as biomarker fatty acid analyses from a variety of mangrove ecosystems would certainly benefit our understanding of the possible contribution of man- grove primary production to adjacent aquatic faunal communities.

\subsection{Quantifying selectivity for local autotrophic food sources}

To be able to correctly interpret consumer stable isotope signatures in such a dynamic ecosystem, (semi-) quantitative and/or qualitative data on the variability in stable isotope signatures (spatial and seasonal) of primary producers were shown to be indispensable. Even though the evidence for selectivity is strong and the observed $\delta^{13} \mathrm{C}$ data are consistent with a dominance of phytoplankton and benthic microalgae at the foodweb basis, any attempt at quantification of the relative contribution of different sources remains difficult. Nevertheless, we can attempt to calculate the overall selectivity of benthic invertebrates for local production (making a few simplifying assumptions, see further) using the premonsoon and post-monsoon dataset provided by this study and our earlier work (Bouillon et al., 2000, 2002a) for data on $\delta^{13} \mathrm{C}_{\mathrm{POC}}$ and data on $\delta^{13} \mathrm{C}$ of invertebrates and sedimentary organic carbon, respectively). For carbon, the sediment organic matter pool and the suspended POC pool show an overall spatial gradient (between the mangrove creeks and the adjacent Kakinada Bay) of about 2.5 and $2.7 \%$, respectively. This variability is much smaller than that expected in phytoplankton and benthic microalgae, as the DIC pool which serves as the substrate for phytoplankton $\mathrm{C}$ fixation exhibits a much larger variability of -on an annual basis-approximately $6.8 \%$ (this study, and own unpubl. $\delta^{13} \mathrm{C}_{\text {DIC }}$ data collected over $>1$ y). Benthic invertebrates were found to display a spatial gradient of approximately 6.9 and $8.8 \%$ during pre- and post-monsoon, respectively. We can then formulate the overall selectivity as:

$\mathrm{SEL}=\left(\frac{\Delta \delta^{13} \mathrm{C}_{\text {invertebrates }}-\Delta \delta^{13} \mathrm{C}_{\mathrm{POC}}}{\Delta \delta^{13} \mathrm{C}_{\mathrm{DIC}}-\Delta \delta^{13} \mathrm{C}_{\mathrm{POC}}}\right) * 100[\%]$

where SEL refers to the overall selectivity, $\Delta \delta^{13}$ $\mathrm{C}_{\text {invertebrates }}$ is the overall gradient in invertebrate $\delta^{13} \mathrm{C}$ values, $\Delta \delta^{13} \mathrm{C}_{\mathrm{DIC}}$ the overall gradient in DIC $\delta^{13} \mathrm{C}$ values (as a proxy for the expected gradient in local 
microalgal carbon sources), and $\Delta \delta^{13} \mathrm{C}_{\mathrm{POC}}$ is the overall gradient in POC $\delta^{13} \mathrm{C}$ values (note that we might similarly have taken sediment organic carbon if we consider deposit feeding or sediment surface grazing to be important).

Thus, if $\Delta \delta^{13} \mathrm{C}_{\text {invertebrates }}=\Delta \delta^{13} \mathrm{C}_{\mathrm{POC}}$, the estimated selectivity is zero (i.e. local phytoplankton or microphytobenthos and terrestrial carbon are used in the proportions in which they occur in the POC pool), whereas $\Delta \delta^{13} \mathrm{C}_{\text {invertebrates }}=\Delta \delta^{13} \mathrm{C}_{\text {DIC }}$ implies a selectivity of $100 \%$ for local microalgal production. The selectivity itself therefore does not directly assess the relative importance of microalgal and terrestrial carbon to the carbon requirements of the invertebrate community, but is rather an indicator of the degree to which the organisms considered are able to distinguish both fractions and select for the more labile microalgal carbon (the mechanisms of this selectivity are not considered). In order to estimate the actual contribution of microalgal production and terrestrial sources, the contribution of the latter two to the POC pool also needs to be taken into account. Applying this to our benthic invertebrate datasets, this suggests a selectivity of approximately $100 \%$ (pre-monsoon) or even $>100 \%$ (postmonsoon). Using the same approach on zooplankton data from the same area (Bouillon et al., 2000) also results in a calculated selectivity higher than $80 \%$. Evidently, if we had used a simple two-end mixing approach with a marine phytoplankton end member (e.g. Chong et al., 2001; Schwamborn et al., 2002), we would have wrongly concluded that mangrove carbon contributes very significantly to the diet of invertebrates in the tidal creeks, and marginally in the bay region. It should be stressed that the proposed estimate for selectivity also has several intrinsic limitations, as it assumes:

(1) that the degree of selectivity is similar along the gradient considered, and

(2) that the relative role of benthic and pelagic microalgae as carbon sources is also uniform along the gradient.

As for the first assumption, one can imagine a situation in which the degree of selectivity will vary locally, e.g. as a function of the relative amounts of terrestrial and microalgal carbon in the POC pool.
However, as our previous work (Bouillon et al., 2000; Bouillon et al., in press) has indicated that the composition of POC does not differ dramatically between the mangroves creeks and adjacent bay, we do not consider this assumption a major limitation to applying our approach in this study. We have no indications as to the validity of the second assumption in our study, but it should be noted that a larger contribution by benthic microalgae - which are known to be more ${ }^{13} \mathrm{C}$-enriched (France, 1995) — in the bay area could explain the estimated selectivity of $>100 \%$ for the post-monsoon data.

Thus, in order to take local variations in the degree of selectivity into account, it would be necessary to make a more reliable estimate of the contribution of different carbon sources to the POC pool at different sites along a mangrove-open water gradient, which is problematic for a number of reaons. First, the $\delta^{13} \mathrm{C}$ values of primary producers in such a dynamic environment will be variable even at a single location, over very short time periods (e.g. diel variations in $\delta^{13} \mathrm{C}_{\mathrm{DIC}}$ of $4 \%$ o have been noted in Gaderu creek, Bouillon et al., in press), and over longer time scales. Consumer $\delta^{13} \mathrm{C}$ values represent an integration over time of these variations. Thus, an accurate characterisation of the phytoplankton or microphytobenthos $\delta^{13} \mathrm{C}$ at a given site remains problematic. Secondly, as the difference between $\delta^{13} \mathrm{C}$ signatures of terrestrial sources and local production can become minimal inside the creeks (monthly averaged $\delta^{13} \mathrm{C}_{\text {DIC }}$ values for mangrove creeks vary between -12.4 and $-5.8 \%$, own unpubl. data), the errors that arise when two-end mixing models are employed to calculate their relative contribution, become unacceptable (see e.g. Phillips and Gregg, 2001). More focussed sampling at specified sites, and the inclusion of other tracers such as $\delta^{13} \mathrm{C}$ in specific biomarker compounds, see e.g. Bidigare et al. (1991) and Boschker and Middelburg (2002) or the analysis of stable isotope ratios in additional elements (in particular, $\delta^{34} \mathrm{~S}$ ) could offer more insights. Nevertheless, as the evidence for selectivity on the whole is beyond question, we feel that -when keeping the inherent limitations in mind- our estimates are valuable in offering a comparative and overall measure of selectivity, which can easily be applied for other systems in which significant gradients in stable isotope ratios 
can be expected (e.g. along estuarine salinity gradients, cf. Fry, 2002).

\section{Acknowledgements}

Financial support was granted by the EC-INCO contract ERB IC18-CT98-0295 and by the Fonds voor Wetenschappelijk Onderzoek (FWO-Vlaanderen) contract G.0118.02. The first author is a post-doctoral fellow with the FWO-Vlaanderen. We are grateful to K. Ratnam and A.V.V.S. Rao for help during various parts of the sample collections, and to two anonymous reviewers, whose constructive comments greatly improved an earlier version of the manuscript.

\section{References}

Bidigare, R.R., Kennicutt II, M.C., Keeney-Kennicutt, W.L., Macko, S.A. 1991. Isolation and purification of chlorophylls a and $\mathrm{b}$ for the determination of stable carbon and nitrogen isotope composition. Anal. Chem. 63, 130-133.

Boschker, H.T.S., Middelburg, J.J., 2002. Stable isotope analysis of biomarkers in microbial ecology. FEMS Microb. Ecol. 40, 85-95.

Bouillon, S., Chandra Mohan, P., Sreenivas, N., Dehairs, F., 2000. Sources of suspended matter and selective feeding by zooplankton in an estuarine mangrove ecosystem, as traced by stable isotopes. Mar. Ecol. Prog. Ser. 208, 79-92.

Bouillon, S., Raman, A.V., Dauby, P., Dehairs, F., 2002a. Carbon and nitrogen stable isotope ratios of subtidal benthic invertebrates in an estuarine mangrove ecosystem (Andhra Pradesh, India). Estuar. Coast. Shelf Sci. 54, 901-913.

Bouillon, S., Koedam, N., Raman, A.V., Dehairs, F., 2002b. Primary producers sustaining macro-invertebrate communities in intertidal mangrove forests. Oecologia 130, 441-448.

Bouillon, S., Frankignoulle, M., Dehairs, F., Velimirov, B., Eiler, A., Etcheber, H., Abril, G., Borges, A.V., in press. Inorganic and organic carbon biogeochemistry in the Gautami Godavari estuary (Andhra Pradesh, India) during pre-monsoon: the local impact of extensive mangrove forests. Glob. Biogeochem. Cyc.

Cai, D.L., Tan, F.C., Edmond, J.M., 1988. Sources and transport of particulate organic carbon in the Amazon River and estuary. Estuar. Coast. Shelf Sci. 26, 1-14.

Chanton, J.P., Lewis, F.G., 1999. Plankton and dissolved inorganic carbon isotopic composition in a river-dominated estuary: Apalachicola Bay. Florida. Estuaries 22, 575-583.

Chong, V.C., Low, C.B., Ichikawa, T., 2001. Contribution of mangrove detritus to juvenile prawn nutrition: a dual stable isotope study in a Malaysian mangrove forest. Mar. Biol. $138,77-86$.

Dehairs, F., Rao, R.G., Chandra Mohan, P., Raman, V., Marguillier,
S., Hellings, L., 2000. Tracing mangrove carbon in suspended matter and aquatic fauna of the Gautami-Godavari Delta, Bay of Bengal (India). Hydrobiologia 431, 225-241.

Dittmar, T., Lara, R.J., 2001. Driving forces behind nutrient and organic matter dynamics in a mangrove tidal creek in North Brazil. Estuar. Coast. Shelf Sci. 52, 249-259.

Dittmar, T., Lara, R.J., Kattner, G., 2001. River or mangrove? Tracing major organic matter sources in tropical Brazilian coastal waters. Mar. Chem. 73, 253-271.

Faganeli, J., Malej, A., Pezdic, J., Malacic, V., 1988. C-N-P ratios and stable $\mathrm{C}$ isotopic ratios as indicators of sources of organic matter in the Gulf of Trieste (Northern Adriatic). Oceanol. Acta $11,377-382$.

Fleming, M., Lin, G., Sternberg, L.S.L., 1990. Influence of mangrove detritus in an estuarine ecosystem. Bull. Mar. Sci. 47, 663-669.

France, R.L., 1995. Carbon-13 enrichment in benthic compared to planktonic algae: foodweb implications. Mar. Ecol. Prog. Ser. 124, 307-312.

France, R.L., Holmquist, J.G., 1997. $\delta^{13} \mathrm{C}$ variability of macroalgae: effects of water motion via baffling by seagrasses and mangroves. Mar. Ecol. Prog. Ser. 149, 305-308.

Fry, B., 2002. Conservative mixing of stable isotopes across estuarine salinity gradients: a conceptual framework for montioring watershed influences on downstream fisheries production. Estuaries 25, 264-271.

Fry, B., Mumford, B.L., Robblee, M.B., 1999. Stable isotope studies of pink shrimp (Farfantepenaeus duorarum Burkenroad) migrations on the southwestern Florida shelf. Bull. Mar. Sci. 65, 419-430.

Gupta, L.P., Subramanian, V., Ittekkot, V., 1997. Biogeochemistry of particulate organic matter transported by the Godavari River, India. Biogeochemistry 38, 103-128.

Hayase, S., Ichikawa, T., Tanaka, K., 1999. Preliminary report on stable isotope ratio analysis for samples from Matang mangrove brackish water ecosystems. J. Agr. Res. Quart. 33, 215-221.

Hellings, L., Dehairs, F., Tackx, M., Keppens, E., Baeyens, W., 1999. Origin and fate of organic carbon in the freshwater part of the Scheldt Estuary as traced by stable carbon isotopic composition. Biogeochemistry 47, 167-186.

Hemminga, M.A., Slim, F.J., Kazungu, J., Ganssen, G.M., Nieuwenhuize, J., Kruyt, N.M., 1994. Carbon outwelling from a mangrove forest with adjacent seagrass beds and coral reefs (Gazi Bay, Kenya). Mar. Ecol. Prog. Ser. 106, 291-301.

Hinga, K.R., Arthur, M.A., Pilson, M.E.Q., Whitaker, D., 1994. Carbon isotope fractionation by marine phytoplankton in culture: the effects of $\mathrm{CO}_{2}$ concentration, $\mathrm{pH}$, temperature, and species. Global Biogeochem. Cyc. 8, 91-102.

Lee, S.Y., 1995. Mangrove outwelling: a review. Hydrobiologia 295, 203-212.

Lee, S.Y., 2000. Carbon dynamics of Deep Bay, eastern Pearl River estuary, China. II: Trophic relationship based on carbon and nitrogen stable isotopes. Mar. Ecol. Prog. Ser. 205, 1-10.

Leggett, M.F., Servos, M.R., Hesslein, R., Johansson, O., Miljard, E.S., Dixon, D.G., 1999. Biogeochemical influences on the carbon isotope signature of Lake Ontario biota. Can. J. Fish. Aquat. Sci. 56, 2211-2218. 
Li, M.S., Lee, S.Y., 1998. Carbon dynamics of Deep Bay, eastern Pearl River Estuary, China. I: A mass balance budget and implications for shorebird conservation. Mar. Ecol. Prog. Ser. 172, $73-87$.

Lin, G., Banks, T., Sternberg, L.O., 1991. Variation in $\delta^{13} \mathrm{C}$ values for the seagrass Thalassia testudinum and its relations to mangrove carbon. Aquat. Bot. 40, 333-341.

Marguillier, S., Van der Velde, G., Dehairs, F., Hemminga, M.A., Rajagopal, S., 1997. Trophic relationships in an interlinked mangrove-seagrass ecosystem as traced by $\delta^{13} \mathrm{C}$ and $\delta^{15} \mathrm{~N}$. Mar. Ecol. Prog. Ser. 151, 115-121.

Middelburg, J.J., Nieuwenhuize, J., 1998. Carbon and nitrogen isotopes in suspended matter and sediments from the Schelde Estuary. Mar. Chem. 60, 217-225.

Mook, W.G., Tan, F.C., 1991. Stable carbon isotopes in rivers and estuaries. In: Degens, E.T., Kempe, S., Richey, J.E. (Eds.), Biogeochemistry of Major World Rivers. SCOPE, John Wiley and Sons Ltd., New York, pp. 245-264.

Ogawa, N., Ogura, N., 1997. Dynamics of particulate organic matter in the Tamagawa estuary and inner Tokyo bay. Estuar. Coast. Shelf Sci. 44, 263-273.

Phillips, D.L., Gregg, J.W., 2001. Uncertainty in source partitioning using stable isotopes. Oecologia 127, 171-179.

Primavera, J.H., 1996. Stable carbon isotope ratios of penaeid juveniles and primary producers in a riverine mangrove in Guimeras, Philippines. Bull. Mar. Sci. 58, 675-683.
Rau, G.H., Teyssie, J.L., Rassoulzadegan, F., Fowler, S.W., 1990 ${ }^{13} \mathrm{C} /{ }^{12} \mathrm{C}$ and ${ }^{15} \mathrm{~N} /{ }^{14} \mathrm{~N}$ varitiations among size-fractionated marine particles: implications for their origin and trophic relationships. Mar. Ecol. Prog. Ser. 59, 33-38.

Rau, G.H., Takahashi, T., Des Marais, D.J., Repeta, K.J., Martin, J.H., 1992. The relationship between $\delta^{13} \mathrm{C}$ of organic matter and $\left[\mathrm{CO}_{2}(\mathrm{aq})\right]$ in ocean surface water: data from a JGOFS site in the northeast Atlantic Ocean and a model. Geochim. Cosmochim. Acta 56, 1413-1419.

Robertson, A.I., Blaber, S.J.M., 1992. Plankton, epibenthos and fish communities. In: Robertson, A.I., Alongi, D.M. (Eds.), Tropical Mangrove Ecosystems. Coastal and Estuarine Studies, vol. 41. Am. Geophys. Un., 329 pp.

Rodelli, M.R., Gearing, J.N., Gearing, P.J., Marshall, N., Sasekumar, A., 1984. Stable isotope ratios as a tracer of mangrove carbon in Malaysian ecosystems. Oecologia 61, 326-333.

Schwamborn, R., Ekau, W., Voss, M., Saint-Paul, U., 2002. How important are mangroves as a carbon source for decapod crustacean larvae in a tropical estuary? Mar. Ecol. Prog. Ser. 229, $195-205$.

Vidy, G., 2000. Estuarine and mangrove ecosystems and the nursery concept: which is which? The case of the Sine Saloum system (Senegal). Wetl. Ecol. Manag. 8, 37-51.

Wafar, S., Untawale, A.G., Wafar, M., 1997. Litter fall and energy flux in a mangrove ecosystem. Estuar. Coast. Shelf Sci. 44, $111-124$. 